\title{
LABOUR TAXATION - A COMPARATIVE STUDY
}

\author{
Lecturer Claudia Florina Radu PhD \\ „Vasile Goldis” Western University of Arad, Faculty of Economics \\ raduclaudiaf@gmail.com \\ Associate Professor Florin Dumiter PhD \\ „Vasile Goldis” Western University of Arad, Faculty of Economics \\ fdumiter@yahoo.com \\ Anca Laura Opret PhD Candidate \\ The Bucharest Academy of Economic Studies \\ ancaopret@yahoo.com
}

(Received February 2015; accepted April 2015)

\begin{abstract}
In our paper we aim to analyze the tax wedge between labor costs and net wage, this being the main indicator for assessing the tax burden on labor. We analyze the components of the tax wedge and its evolution in time, in the OECD countries and in Romania. In this way we can get an image of the total labor cost, observing that our country belongs to countries where labor taxes have a very high level. Thus, from our analysis we showed that in Romania the tax wedge is around $42 \%$, while the OECD average was only $35.9 \%$. In these circumstances it is necessary to adopt certain measures for shifting the tax burden from labor to other tax bases, with the purpose of a fiscal relaxation of labor income.
\end{abstract}

Key words: labor taxes, tax wedge, tax burden, social contributions

JEL Classification: H24, J32

\section{Introduction}

Taxes on labor produce substantial resources for budgets of many countries and in a lot of cases it is preferred a progressive taxation of income from wages. In many countries there is a rather high tax burden on individuals with average income.

However, it is important to notice that labor taxes are high in many countries, mainly due to high social security contributions levied on wages. These social contributions have the purpose to finance social security programs, which are very expensive especially in the European countries.

In order to measure the tax burden on labor, OECD countries use the tax wedge. This is the gap between labor costs and net wage and a high tax wedge appears mainly as a consequence of high social contributions.

Tax wedge is a significant part of total labor costs, having a great importance in research, because a high tax wedge has negative effects on the labor market income and causes high levels of unemployment. So this produces a decrease of labor supply and employment, and also an increase of unemployment. Labor taxes 
Radu, C.F., Dumiter, F., Opret, A.L. (2015)

Labour taxation - a comparative study

determine employers to pay more and employees to receive less (Trpeski and Tashevska, 2012).

Regarding recommendations on labor taxation, these aim two aspects: either reducing the overall tax burden on labor or its decrease only for the most disadvantaged groups (low-income individuals). Of course, broadening the tax base and simplifying the tax system might produce useful effects, in order to increase revenues collected.

High tax burden on labor can be reduced by transferring a part of it to other tax bases. In this regard it would be useful to increase consumption taxes, the environment or property taxes. Some EU countries have adopted the measure of increasing VAT rates and excise rates in order to reduce labor taxes. However, tax burden reduction should target especially low-skilled workers and second income earners, because in their case there is a high elasticity of labor supply.

Precisely for this reason it is often recommended the reduction of taxation for individuals with the lowest incomes, because this would stimulate labor supply and would contribute to economic recovery.

High social contributions diminish net wages of employees, but also their incentive to work. In general, high taxation and various government limitations of the market reduce labor supply and the prospect of increasing productive capital. Thus economic progress and the improvement of citizens' living standards are endangered (Urban, 2009).

Therefore we must take into account the fact that in order to reduce the tax burden on labor it is important to diminish social contributions, especially for employers. This can be compensated for example by increasing VAT rates. If labor costs are lower than domestic products will become cheaper and this way exports are stimulated.

In our paper we aim to analyze the tax wedge between labor costs and net wage in the OECD countries and in Romania, making a comparison between the OECD average and the level from our country. We also highlight the evolution in time of the tax wedge from our country and from OECD countries.

\section{Literature review}

Labor taxation represented the subject of several previous analyzes, of diverse authors. The literature suggests that a higher tax wedge causes higher rates of unemployment and lower levels of employment and labor force participation. Generally it is admitted that higher taxes on labor have adverse effects upon the labor market income. There are also researches which show that negative effects of labor taxation on unemployment and economic growth are more pronounced in Europe (excluding Scandinavia) than in other OECD countries (Trpeski and Tashevska, 2012, p. 574). 
Radu, C.F., Dumiter, F., Opret, A.L. (2015)

Labour taxation - a comparative study

Although most studies confirm the negative effect of the tax wedge on employment rates, however its magnitude depends on the institutional characteristics of each labor market (Trpeski and Tashevska, 2012, p. 574).

Pomerleau (2014) studied labor taxation in USA and concluded that even in the US, which has a lower tax burden on labor than in most OECD countries, individuals with average salary paid about a third of their income in the form of taxes. On the other hand, it is true that OECD countries, especially the EU provides generous social security programs. However their employees pay a price too high for them.

In order to reduce labor taxation it was mentioned the solution of shifting the tax burden from labor to other tax bases. This is possible for countries with a low tax burden in terms of consumption taxes, taxes on property or the environment. These three categories of taxes belong of those that are the least detrimental to growth. But it is important to mention that consumption is best suited for this purpose, since the revenue generated by the other two taxes are much lower. In particular, countries such as Belgium, France, Italy, Latvia, Hungary, Romania and to a lesser extent Germany, Netherlands, Austria, Finland, Czech Republic and Sweden appear to have the challenge and the opportunity to reduce the tax burden on labor, by increasing those taxes which are the least detrimental to economic growth (Tax Reforms in EU Member States, 2013, p. 45-47).

Then Piketty and Saez (2012, p. 1) pointed out that social welfare is higher when resources are distributed more equally, but redistributive taxes and transfers may adversely affect the incentive to work and earn income. This creates the classic trade-off between equity and efficiency, which stands at the basis of the problem of optimal labor taxation.

Hutsebaut (2013, p. 8) brings into discussion the fact that despite the general consensus in the EU regarding the need to reduce the tax burden on labor and to shift the tax burden to other tax bases, the ITR (Implicit tax rate) on labor decreased on average only with 0.7 percentage points in the EU between 2000 and 2010 , from $36.7 \%$ to $36 \%$. Then in 2010 this downward trend was reversed and the tax burden on labor started to increase again in more than half of EU countries. This aspect has been highlighted in other studies too. Thus, despite a broad consensus concerning the reduction of labor taxes, high levels of the Implicit tax rate on labor confirms the difficulty of achieving this. The tax burden on labor is composed of personal income taxes and social contributions (Taxation trends in the European Union, 2013, p. 32).

Eugène et al. (2013, p. 27) talk about the fact that many European countries, especially Belgium, present a high level of taxation of labor income. But international economic institutions warn that this high taxation may produce distortions in labor supply and therefore insist on the need of transferring a part of 
Radu, C.F., Dumiter, F., Opret, A.L. (2015)

Labour taxation - a comparative study

the tax burden from labor to other sources of income. Therefore must be found new potential revenues.

According to the European strategy 2020, increasing labor taxes should be avoided. Member States should shift the tax burden from labor to energy and environmental taxes, so the EU would not remain an area of high tax burden on labor, compared to other developed countries. At the same time the transfer of the burden from labor to indirect taxes should be accompanied by policies of increasing tax compliance (Tax burden on labor, European Commission 2014, p. 1-3).

There are also other authors who present the tax wedge as one of the significant factors causing the rapid increase of unemployment levels in Europe since 1960 and also one of the important reasons for which the decrease of unemployment proved so difficult (Morawski and Myck, 2007, p. 2).

The empirical literature focusing on the factors that influence the unemployment rate often shows that the tax wedge can explain a large part of the rise of unemployment in many OECD countries. But from theoretical perspective, it depends on who ultimately bears the additional tax burden, meaning employers or employees (Azemar and Desbordes, 2009, p. 2).

\section{Methodology}

The data used in our paper are taken from the OECD's database. First we aim to analyze the tax wedge between labor costs and net wage from the OECD countries, identifying countries where it has the highest levels and respectively the lowest. Our analysis takes into account both the size of labor's tax wedge and its components. Then we focus on the level of the tax wedge from our country, showing also its evolution in time.

\section{Results and discussions}

In our paper we intend to analyze the taxes - social contributions and income tax which are levied on wages, concerning the employee and the employer. This will give us an overall image of the tax burden at the level of the companies and employees.

When analyzing the tax burden on wages a big importance has the gap between total labor cost for the employer and the net wage of the employee. This is called tax wedge and is calculated by adding the personal income tax and social contributions of both employers and employees and then this sum is divided to total labor cost for the employer. What it is observed is that in most OECD countries, this tax wedge is smaller for families with children than for single individuals (at the same wage level).

In 2013 the tax wedge increased compared to 2012 in 21 of the 34 OECD countries, it decreased in 12 countries and remained unchanged in one country. 
Radu, C.F., Dumiter, F., Opret, A.L. (2015)

Labour taxation - a comparative study

Responsible for this increase was in the greatest extent the personal income tax, which presented a growth in 20 OECD countries. The largest increase has been in Portugal, with 3.5 percentage points. At the same time the tax burden decreased in some countries due to changes occurred in personal income tax and employers' social contributions. Thus the greatest reduction occurred in the Netherlands (1.8 percentage points), Greece (1.4) and France (1.2). We mention that France introduced a tax credit for competitiveness and employment (OECD Taxing Wages 2014, p. 12).

We firstly present how the tax wedge evolved in OECD countries between 20002013, for a single person with average wage. This indicator is called the average tax wedge. Then we highlight the component elements of the tax wedge.

Table 1. Evolution of average tax wedge in OECD countries during 2000-2013

\begin{tabular}{|l|c|c|c|c|c|c|c|}
\hline \multicolumn{1}{|c|}{ Countries } & $\mathbf{2 0 0 0}$ & $\mathbf{2 0 0 5}$ & $\mathbf{2 0 0 9}$ & $\mathbf{2 0 1 0}$ & $\mathbf{2 0 1 2}$ & $\mathbf{2 0 1 3}$ & dif 2013-2000 \\
\hline Australia & 31,01 & 28,51 & 26,75 & 26,83 & 27,21 & 27,41 & $-3,60$ \\
\hline Austria & 47,31 & 48,14 & 47,95 & 48,17 & 48,84 & 49,12 & 1,81 \\
\hline Belgium & 57,10 & 55,51 & 55,65 & 55,93 & 55,99 & 55,80 & $-1,30$ \\
\hline Canada & 32,89 & 31,87 & 30,53 & 30,42 & 30,82 & 31,06 & $-1,83$ \\
\hline Chile & 7,00 & 7,00 & 7,00 & 7,00 & 7,00 & 7,00 & 0,00 \\
\hline Czech Republic & 42,59 & 43,73 & 42,01 & 42,13 & 42,46 & 42,38 & $-0,21$ \\
\hline Denmark & 44,10 & 40,92 & 39,53 & 38,30 & 38,55 & 38,24 & $-5,86$ \\
\hline Estonia & 41,31 & 39,92 & 39,17 & 40,09 & 40,41 & 39,90 & $-1,41$ \\
\hline Finland & 47,52 & 44,39 & 42,50 & 42,29 & 42,56 & 43,12 & $-4,40$ \\
\hline France & 50,43 & 50,51 & 49,84 & 49,90 & 50,13 & 48,92 & $-1,51$ \\
\hline Germany & 52,86 & 52,13 & 50,79 & 49,05 & 49,63 & 49,33 & $-3,53$ \\
\hline Greece & 39,07 & 41,25 & 41,29 & 40,06 & 42,91 & 41,56 & 2,49 \\
\hline Hungary & 54,68 & 51,07 & 53,10 & 46,61 & 49,52 & 49,03 & $-5,65$ \\
\hline Iceland & 28,83 & 32,05 & 30,53 & 33,36 & 33,40 & 33,45 & 4,62 \\
\hline Ireland & 28,87 & 23,47 & 24,74 & 25,83 & 25,91 & 26,60 & $-2,27$ \\
\hline Israel & 29,58 & 25,52 & 21,30 & 20,72 & 20,39 & 20,66 & $-8,92$ \\
\hline Italy & 47,08 & 45,91 & 46,79 & 47,17 & 47,70 & 47,78 & 0,70 \\
\hline Japan & 24,75 & 27,74 & 29,18 & 30,23 & 31,28 & 31,64 & 6,89 \\
\hline Korea & 16,36 & 17,31 & 19,47 & 20,15 & 21,05 & 21,41 & 5,05 \\
\hline Luxembourg & 37,10 & 34,72 & 33,87 & 34,33 & 35,92 & 37,01 & $-0,09$ \\
\hline Mexico & 12,40 & 14,69 & 15,31 & 15,53 & 18,99 & 19,22 & 6,82 \\
\hline Netherlands & 40,04 & 38,92 & 38,02 & 38,10 & 38,72 & 36,94 & $-3,10$ \\
\hline New Zealand & 19,37 & 20,03 & 18,07 & 16,99 & 16,39 & 16,89 & $-2,48$ \\
\hline Norway & 38,56 & 37,25 & 37,30 & 37,29 & 37,42 & 37,34 & $-1,22$ \\
\hline Poland & 38,17 & 38,70 & 34,12 & 34,21 & 35,51 & 35,56 & $-2,61$ \\
\hline Portugal & 37,33 & 36,80 & 36,54 & 37,13 & 37,60 & 41,15 & 3,82 \\
\hline Slovak Republic & 41,86 & 38,01 & 37,72 & 37,92 & 39,62 & 41,13 & $-0,73$ \\
\hline Slovenia & 46,25 & 45,55 & 42,24 & 42,54 & 42,50 & 42,34 & $-3,91$ \\
\hline Spain & 38,63 & 38,97 & 38,26 & 39,75 & 40,62 & 40,66 & 2,03 \\
\hline Sweden & 50,14 & 48,05 & 43,23 & 42,76 & 42,86 & 42,93 & $-7,21$ \\
\hline Switzerland & 22,87 & 22,22 & 21,98 & 22,10 & 21,95 & 21,99 & $-0,88$ \\
\hline Turkey & 40,36 & 42,80 & 37,40 & 37,88 & 38,38 & 38,64 & $-1,72$ \\
\hline & & & & & & & \\
\hline
\end{tabular}


Radu, C.F., Dumiter, F., Opret, A.L. (2015)

Labour taxation - a comparative study

\begin{tabular}{|l|c|c|c|c|c|c|c|}
\hline United Kingdom & 32,59 & 33,94 & 32,41 & 32,58 & 32,10 & 31,48 & $-1,11$ \\
\hline United States & 30,36 & 29,75 & 30,05 & 30,46 & 29,82 & 31,33 & 0,97 \\
\hline OECD - Average & 36,75 & 36,10 & 35,14 & 35,11 & 35,71 & 35,85 & $-0,90$ \\
\hline
\end{tabular}

Source: Taxing Wages - Comparative tables, www.oecd.org

From Table 1 we can see that the average tax wedge increased the most during 2000-2013 in Mexico and Japan, with nearly 7 percentage points. It also declined the most in Sweden with 7 percentage points and in Hungary, with 5 percentage points. Chile is the only country where it remained constant. But in 23 of the 34 OECD countries, the average tax wedge decreased in the analyzed period, and therefore the OECD average fell by almost 1 percentage point.

Figure 1 presents the evolution of tax wedge, as the average of OECD countries over the period 2000-2013.

Figure 1. Evolution of tax wedge as OECD average during 2000-2013

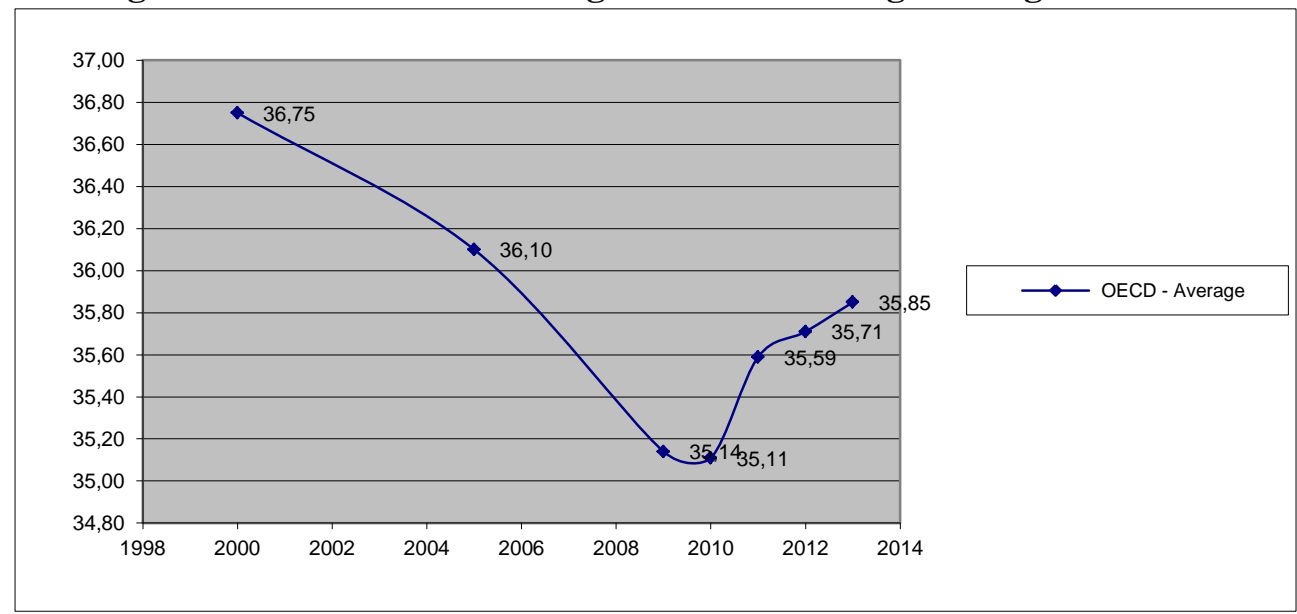

Source: self processing

As we can observe the tax wedge as OECD average had a decreasing trend between 2000-2010, when it fell from $36.75 \%$ to $35.11 \%$. But since 2011 its evolution was one of increasing, its value growing slightly to $35.85 \%$ in 2013 . We mention that 2013 is the last year for which data were available for OECD countries.

Figure 2 highlights the tax wedge between total labor costs for the employer and the net wage, on its three components: personal income tax, employee and employer social security contributions. The amounts correspond to single individuals without children, having the average wage. 
Radu, C.F., Dumiter, F., Opret, A.L. (2015)

Labour taxation - a comparative study

Figure 2. Income tax plus employees and employers social security contributions, as \% of labour costs, 2013 (tax wedge, for a single person with average wage)

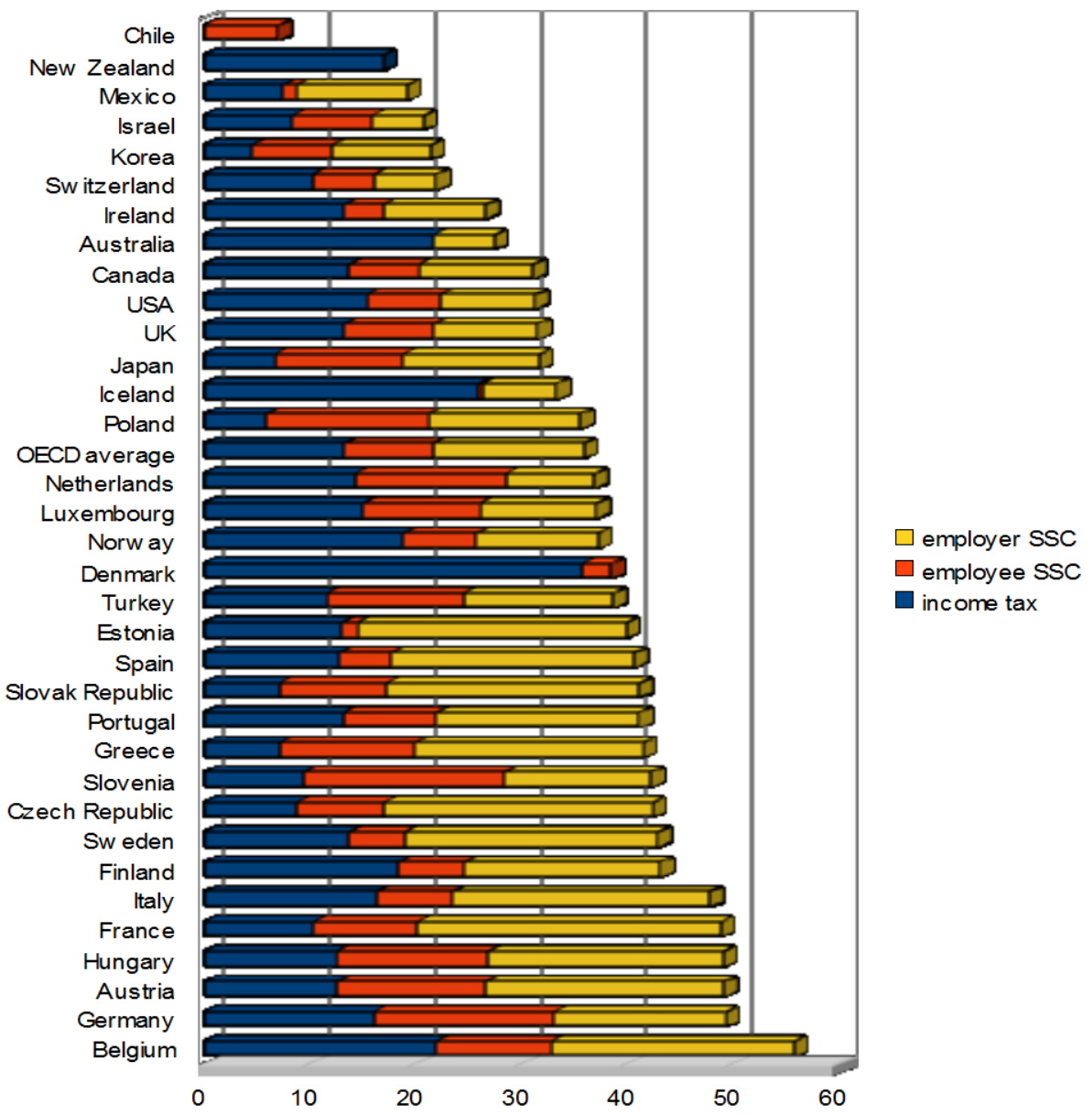

Source: self processing, using data from OECD (2014), Taxing Wages

When referring to the components of tax wedge, we can make some specifications. Thus, related to personal income tax, we can see that it has zero value in Chile, but here employers' social contributions are also missing, so there remain only employees' social contributions. Then, as a feature for New Zealand, we find only the personal income tax, while social contributions are missing. Personal income tax presents the highest share of labor costs in countries such as Denmark (35.8\%), 
Radu, C.F., Dumiter, F., Opret, A.L. (2015)

Labour taxation - a comparative study

Iceland (25.9\%), Belgium (22\%) and Australia (21.8\%). Employees' social contributions have the largest share in Slovenia (19\%) and Germany (17.1\%), while in Australia they are missing. Also, employers' social contributions have a share of over $20 \%$ in 11 OECD countries and the highest values were found in France $(28.7 \%)$, then in Estonia and the Czech Republic, with $25.4 \%$. But in Denmark, New Zealand and Chile they are missing.

Next we analyze the tax burden on the level of employee, highlighting the share of income tax and social contributions levied in gross wage.

Figure 3 shows income tax plus employee social contributions as a percentage of gross wage, at the level of average earnings, in OECD countries.

As we can see from Figure 3 in most OECD countries, namely in 23 of them, the share of income tax in gross wage is higher than the share of employees' social security contributions, meaning that personal income tax exerts a higher tax burden on employees than social contributions. In fact in seven countries the share of personal income tax exceeds $20 \%$ and Denmark distinguishes with a share of $35.8 \%$. Furthermore, Chile is the only OECD country where individuals do not pay personal income tax. Then related to social contributions, we observe that in Australia and New Zealand they are missing, and in some countries they have a very low share. It is about: Iceland, Mexico, Estonia and Denmark. At the opposite pole are Germany and Slovenia, where the share of employees' social contributions in gross income is over 20\%. In fact in 11 OECD countries, the share of employees' social contributions exceeds the share of personal income tax, meaning that, here, employees' social contributions are more heavy for employees than income tax. We also notice that in Netherlands and Czech Republic their shares are almost equal However, we have to take into consideration that high (or low) marginal tax rates do not necessarily mean high (or low) due charges. Thus deductions granted, associated to personal circumstances of the employee, can counterbalance the effect of rates level. Therefore another important aspect in analyzing the tax burden on labor is the tax treatment of families with children, because in many OECD countries families with children are fiscal-advantaged compared to single individuals.

Next we compare the tax wedge between labour costs for the employer and the employee's net pay, taking into account the type of family. Thus we will compare this tax wedge for single individuals without children and for families with 2 children (of which only one family member works), taking into account the average wage. 
Radu, C.F., Dumiter, F., Opret, A.L. (2015)

Labour taxation - a comparative study

Figure 3. Income tax plus employee social security contributions, as \% of gross wage (at the level of average wage), 2013

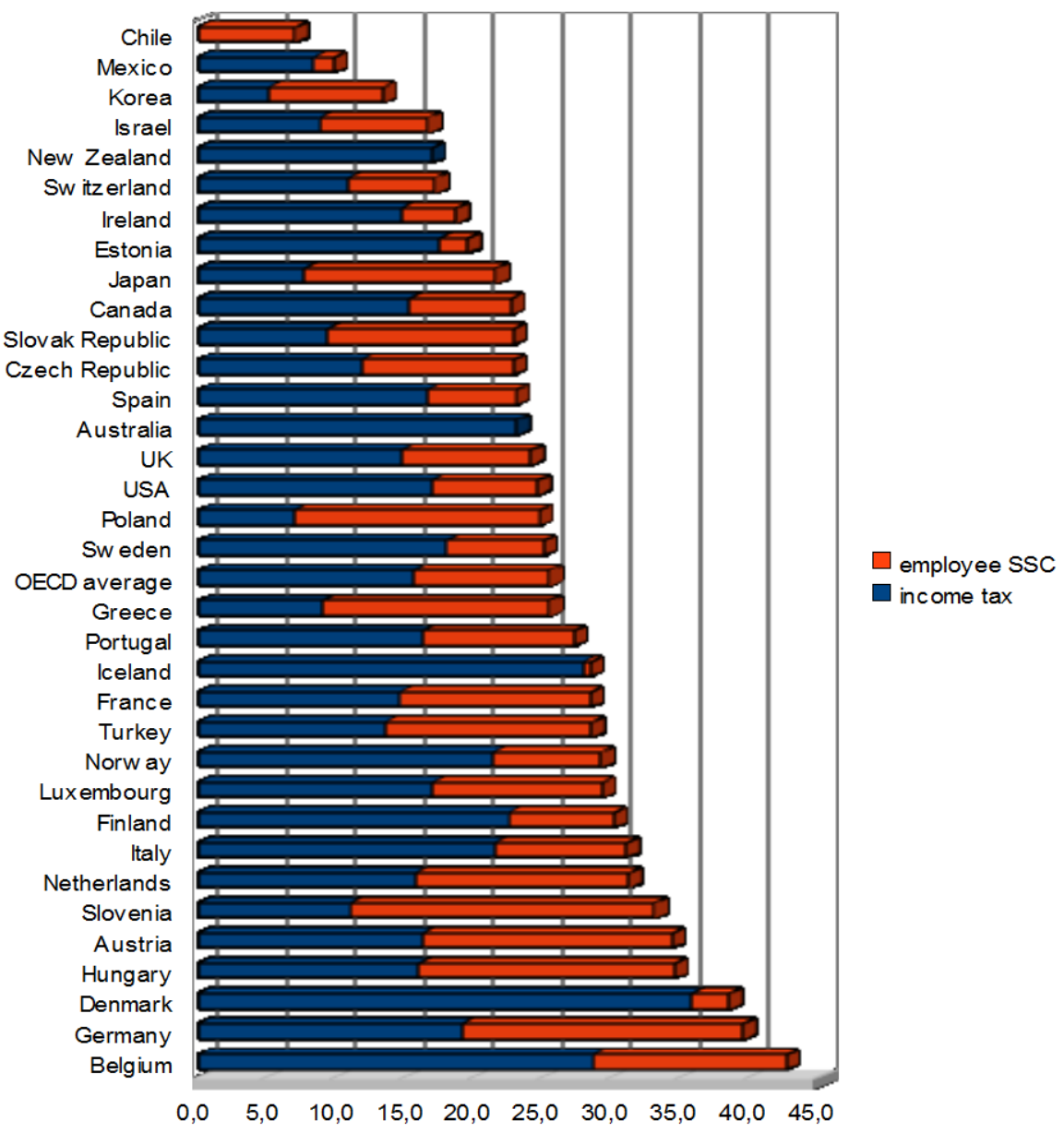

Source: self processing, using data from OECD (2014), Taxing Wages

Figure 4 shows the tax wedge compared by family type.

We see from Figure 4 that there are big differences between the OECD countries in terms of tax wedge. In general we find that the level of this tax wedge is lower for families with two children and one employee, than in the case of single individuals without children, since many OECD countries provide a fiscal benefit to families 
Radu, C.F., Dumiter, F., Opret, A.L. (2015)

Labour taxation - a comparative study

with children, through advantageous tax treatment and/or cash transfers (OECD Taxing Wages 2014, p. 23).

Figure 4. Comparison of tax wedge in function of family type, 2013, (\%)

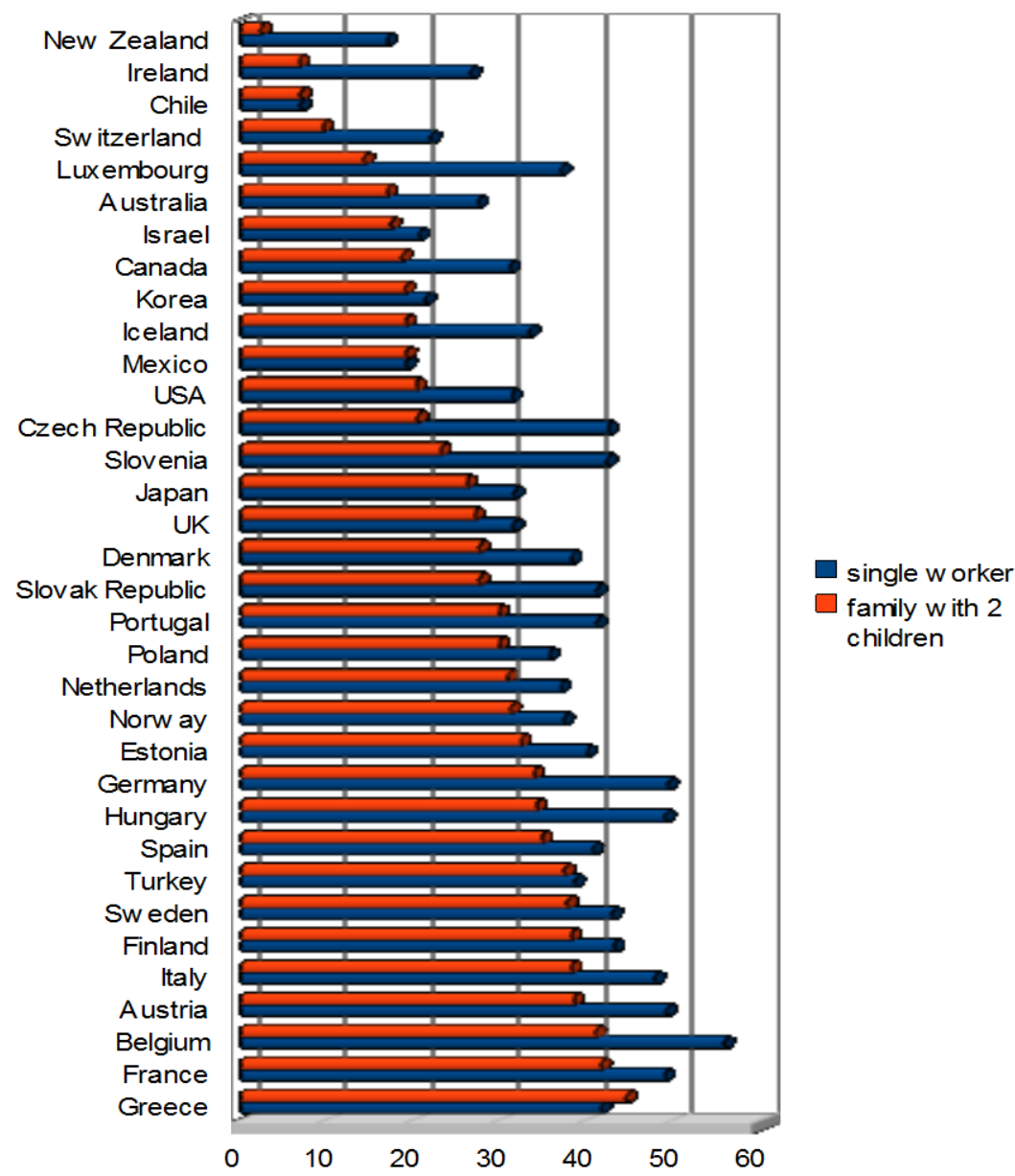

Source: self processing, using data from OECD (2014), Taxing Wages

We can observe that in two countries: Mexico and Chile there is no difference between the tax wedge by family type. In two other countries - Korea and Turkey the difference is very small. At the opposite pole are Luxembourg and Czech Republic, where families with children pay $20 \%$ less than single individuals without children. In the same time, in 15 countries families with children pay $10 \%$ 
Radu, C.F., Dumiter, F., Opret, A.L. (2015)

Labour taxation - a comparative study

less than single individuals. Greece is the only country where the tax wedge for families with children is $2.9 \%$ higher than for single individuals.

The fiscal preference for families with children increased in 2013 compared to 2012 in seven OECD countries: Belgium, Czech Republic, France, Italy, Luxembourg, Portugal and Switzerland. Instead the effects of tax changes on the tax wedge were independent of the family type in Chile, Denmark, Ireland, Japan, Mexico and Turkey (OECD, Taxing Wages 2014, p. 23).

We also mention that in the US, by Child Tax Credit and personal deduction the tax burden of families with two children has been reduced compared to the tax wedge for single persons without children. Also low-income individuals with children benefit of EITC - Earned Income Tax Credit (Pomerleau, 2014).

In the following we analyze the evolution of labour's tax wedge from Romania on the period 2009-2015. We mention that our analysis refers to single individuals with average earnings.

Table 2 shows the calculation of the tax wedge in our country, in the case of an employee with average wage, during 2009-2015 and Figure 5 shows the time evolution of the tax wedge in Romania.

Table 2 shows us firstly the tax burden on the level of an employee with average wage and then the tax wedge between labor costs and net wage.

Table 2. Tax wedge in Romania during 2009-2015 (RON)

\begin{tabular}{|c|c|c|c|c|c|c|c|}
\hline Employee & 2009 & 2010 & 2011 & 2012 & 2013 & 2014 & 2015 \\
\hline Average gross income & 1693 & 1836 & 2022 & 2117 & 2223 & 2298 & 2415 \\
\hline $\begin{array}{c}\text { Total employee social } \\
\text { contributions }\end{array}$ & 279 & 303 & 333 & 349 & 366 & 378 & 398 \\
\hline Income tax & 199 & 221 & 249 & 265 & 281 & 293 & 310 \\
\hline Income tax + SSC & 478 & 524 & 582 & 614 & 647 & 671 & 708 \\
\hline $\begin{array}{c}\text { Tax burden for } \\
\text { employee }\end{array}$ & $28 \%$ & $29 \%$ & $29 \%$ & $29 \%$ & $29 \%$ & $29 \%$ & $29 \%$ \\
\hline \multicolumn{8}{|l|}{ Employer } \\
\hline $\begin{array}{c}\text { Total employer social } \\
\text { contributions }\end{array}$ & 474 & 514 & 566 & 593 & 622 & 643 & 555 \\
\hline $\begin{array}{c}\text { Income tax + } \\
\text { employee SSC + } \\
\text { employer SSC }\end{array}$ & 952 & 1038 & 1148 & 1207 & 1269 & 1314 & 1263 \\
\hline Net wage & 1215 & 1312 & 1440 & 1503 & 1576 & 1627 & 1707 \\
\hline Labour costs & 2167 & 2350 & 2588 & 2710 & 2845 & 2941 & 2970 \\
\hline Tax wedge & $43,93 \%$ & $44,17 \%$ & $44,36 \%$ & $44,54 \%$ & $44,60 \%$ & $44,68 \%$ & $42,53 \%$ \\
\hline
\end{tabular}

Source: self processing

The tax burden at the level of employee is obtained by dividing the sum of income tax and employee social contributions to gross wage. We observe that in the analyzed period the tax burden in Romania increased slightly in 2010 from $28 \%$ to $29 \%$ and then remained constant at $29 \%$. In the case of OECD countries the 
Radu, C.F., Dumiter, F., Opret, A.L. (2015)

Labour taxation - a comparative study

average is $25.5 \%$ (as we see from Figure 3). We conclude, therefore, that the tax burden for an employee with average wage in Romania is 4 percentage points higher than the OECD average, which is due to high social contributions paid by employees. We also mention that the tax burden for employees is the highest in Belgium (42.6\%), Germany (39.5\%) and Denmark (38.5\%) and the lowest in Mexico (9.8\%) and Chile (7\%).

Figure 5. Evolution of the tax wedge in Romania, 2009-2015

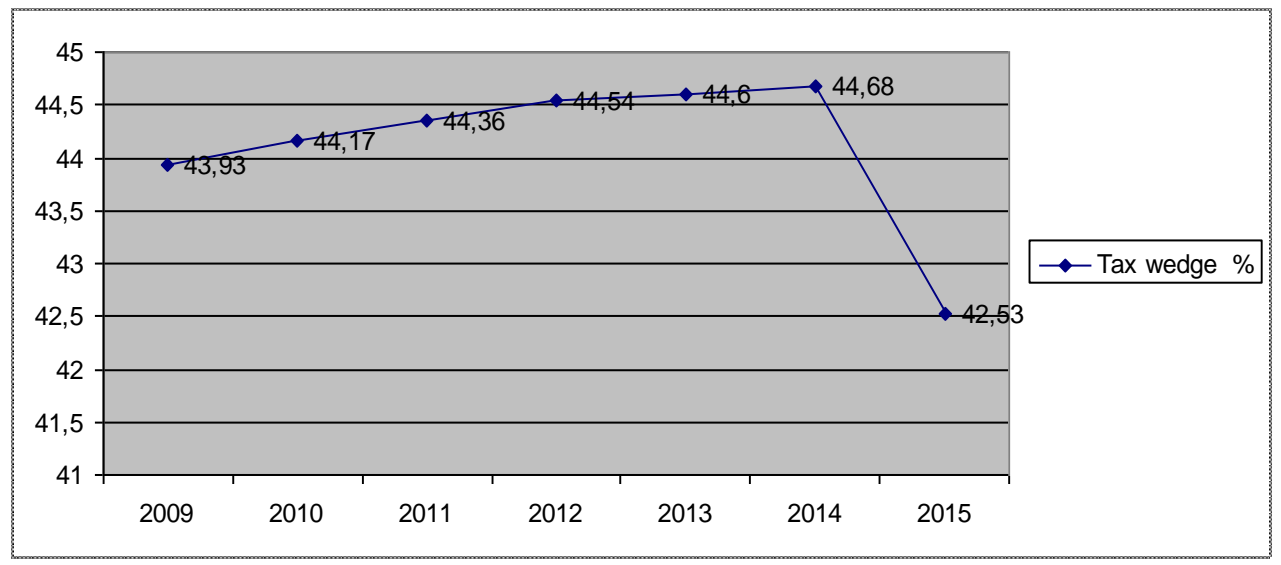

Source: self processing

Regarding the tax wedge in Romania, it increased slightly since 2009 until 2014 from $43.93 \%$ to $44.68 \%$. We mention that in the analyzed period the average gross wage also increased. Then in 2015 , due to reduction of employers' social security contributions by 5 percentage points, we are witnessing a decrease of the tax wedge from $44.68 \%$ to $42.53 \%$. The tax wedge is obtained by dividing the sum of income tax, employee social contributions and employer social contributions to labour costs.

We make now a parallel between the evolution of Romania's tax wedge and the OECD average, mentioning that in our country, although it increased until 2014, when there was a slight decrease, each year its value was around $44 \%$ (except in 2015 when it reached $42.53 \%$ ). This is a rather high value compared to the OECD average, which although started to increase slightly from 2010, was around 35\%.

Analyzing the OECD average of tax wedge for 2013 (the latest year available) we see that it is of $35.9 \%$, so this means that in our country we have a tax wedge between labour costs and net wage by 8 percentage points higher than the OECD area average. Sweden, Czech Republic and Slovenia present a similar tax wedge with that of our country, of $42 \%$. The highest values were in Belgium (55.8\%) and 
Radu, C.F., Dumiter, F., Opret, A.L. (2015)

Labour taxation - a comparative study

Germany (49.3\%) and the lowest in New Zealand (16.9\%) and Chile (7\%). Therefore we can conclude that the level of tax wedge in our country is very high and in only seven OECD countries this exceeds $42 \%$. That is why it would be desirable a decrease of the tax wedge in our country.

However for having a complete picture of the employees' tax burden should be considered also indirect taxes, because they also exert a high burden on individuals, and even if they are not subject of these taxes, they bear them. But we also have to take into account the derisory level of wages from our country that are much lower than in Western countries, while most of the prices are aligned with those of the EU.

\section{Conclusions}

Although certain measures have been taken in order to decrease labour taxation, the tax burden on labor remains high in many countries.

In these conditions it is important to know the means by which the tax burden on labor can be reduced. Firstly it might be achieved by reducing marginal tax rates, especially for low wage levels (Radu, 2009, p. 72). Then another important aspect is the decrease of social contribution rates, which would boost labor supply and demand. We mention that in order to reduce labor taxes several countries have transferred the tax burden from labor to other tax bases. Therefore, the reduction of taxes on labor can be compensated by the increase of VAT or excise duty, and another option would be to increase property taxes or environmental taxes.

A number of empirical studies showed that shifting the tax burden from labor to environmental taxes might have positive effects, the unemployment rate declining by $0.1-0.3$ percentage points (Leibfritz et al., 1997, p. 47).

From our analysis it resulted that the tax burden on labor in our country is very high compared to the OECD countries and this is mainly due to high social security contributions. So we observed that the tax wedge in Romania, having currently the value of $42.53 \%$ is 6 percentage points higher than the OECD average (of $35.85 \%$ for 2013). Also in only seven OECD countries the tax wedge exceeds $42 \%$, meaning that we make part of the countries with a very high tax wedge. For this reason it would be useful to continue the process of decreasing social contributions. In this context it is important to mention that the high level of compulsory levies upon work in our country and the low level of wages have two negative effects: the emigration of workers to other countries, so that the number of people working abroad is quite high and secondly, untaxed labor. This is quite worrying and in our opinion it would be necessary the rapid adoption of some measures.

Indeed untaxed labor is high and that is why the reduction of social contributions is a good measure. But we also have to take into account that now the average wage in Romania is far below the level of EU countries. 
Radu, C.F., Dumiter, F., Opret, A.L. (2015)

Labour taxation - a comparative study

The fiscal relaxation process by reducing social security contributions should be continued, because taxation lowering is in the benefit of taxpayers and will bring extra revenue to the state budget (Rusu, 2005). Another positive effect of reducing labor costs, however small it is, consists in increasing the competitiveness of Romanian products. A reduction of social contributions in the future and even a most significant one would be positively appreciated.

\section{References:}

1. Azemar, C., Desbordes, R. (2009). Who Ultimately Bears the Burden of Greater Non-Wage Labour costs?, Retrieved from etpf.org/papers/44SSC.pdf Accessed november 2014

2. Eugène, B., Bisciari, P., Nautet, M., Stinglhamber, P., Van Meensel, L. (2013). Trends in tax systems in the EU, Retrieved from http://www.nbb.be/doc/oc/repec/ecrart/ecorevIII2013 H2.pdf Accessed november 2014

3. Hutsebaut, M., (2013). Taxation policies from a European perspective, Retrieved from perc.ituc-csi.org/IMG/pdf/taxation_policies_from_a_european_ perspective_

martin_hutsebaut_cle07eebf.pdf Accessed december 2014

4. Leibfritz, W., Thornton, J., Bibbee, A., (1997). Taxation and economic performance, OECD Economics Department Working Papers No. 176

5. Morawski, L., Myck, M. (2007). 'Klin'-ing up: reforming taxes on labour in Poland, Retrieved

from

seminar.wne.uw.edu.pl/uploads/Main/klin_paper_11DecEN.pdf Accessed december 2014

6. Piketty, T., Saez, E. (2012). Optimal labor income taxation, Retrieved from https://ideas.repec.org/p/nbr/nberwo/18521.html Accessed november 2014

7. Pomerleau, K. (2014). A Comparison of the Tax Burden on Labor in the OECD, Retrieved from http://taxfoundation.org/article/comparison-tax-burden-labor-oecd Accessed november 2014

8. Radu, C. F. (2009), Presiunea fiscala, Ed. Mega, Cluj-Napoca

9. Rusu F., (2005) Majorarea TVA, efect de bumerang, Retrieved from http://www.wall-street.ro/articol/Economie/6080/Majorarea-TVA-efect-debumerang.html Accessed december 2014

10. Trpeski, P., Tashevska, B. (2012). Labour tax wedge in the republic of Macedonia - Trends and international comparison, Retrieved from oeconomica.uab.ro/upload/lucrari/1420122/24.pdf Accessed december 2014 11. Urban, I. (2009). The tax burden on labour in Croatia, Retrieved from ijf.hr/eng/newsletter/47.pdf Accessed december 2014 
Radu, C.F., Dumiter, F., Opret, A.L. (2015)

Labour taxation - a comparative study

12. OECD (2014), Taxing Wages 2014, OECD Publishing, Retrieved from http://dx.doi.org/10.1787/tax_wages-2014-en Accessed november 2014 13. Tax burden on labour, European Commission, 2014, Retrieved from ec.europa.eu/europe2020/pdf/themes/21_tax_burden_on_labour.pdf Accessed december 2014

14. Tax reforms in EU Member States, 2013, Retrieved from protothema.gr/files/1/2013/10/09/taxation_paper_38.pdf Accessed december 2014 15. Taxation trends in the European Union - Data for the EU Member States, Iceland and Norway, 2013 edition, Retrieved from ec.europa.eu/taxation_customs/resources/documents/taxation/gen_info/ economic_analysis/tax_structures/2013/report.pdf Accessed november 2014. 